\title{
Determining the Students' Media Regime in Ministry of Education
}

\author{
Maryam Najjar Ajampour ${ }^{1,2}$, Shahnaz Hashemi ${ }^{1,2^{*}}$ \\ ${ }^{I}$ Department of humanity,Social Communication Sciences, Ardabil Science and Research Branch, Islamic Azad \\ University, Ardabil, Iran \\ ${ }^{2}$ Department of humanity, Social Communication Sciences, Ardabil Branch,Islamic Azad University, , Ardabil,
} Iran

\begin{abstract}
Since the media plays an important role in forming and changing the attitude, thought and behavior of the audience, teaching and recognizing the methods and performances of the media gain importance. The aim of the present study is to determine the students' media regime in Tehran's Ministry of Education, district 12 . This research is applicable in terms of aim, descriptive-survey in terms of methodology, quantitative in terms of the relationship between the variables and cross sectional in terms of time. The statistical population of this study includes all the students of high schools (first three-year and second three-year grades) in Tehran's Ministry of Education, district 12, who were selected by means of Cochran's sample size formula and simple random sampling (370 individuals). The main tools of this research are library studies and questionnaire, which include the components of the study. The advisor has confirmed the face validity and content validity of the questionnaire and its reliability was determined by means of Cronbach's Alpha (0.84). The data has been analyzed through descriptive and referential statistics and SPSS software (version 22). According to the results, students use the media with different goals, in other words, they use it according to their needs. The students selected "entertainment" as the most important reason of using the media. The results also indicated that students have more tendencies to use the media (television, the Internet, satellite, social networks, playing computer games etc.) than before. On the other hand, students are less eager than before to read newspapers and magazines and do their homework. Students' media literacy level is not sufficient and they spend time using the media. They also have different styles of using the media and search for some goals. In other words, students use the media for different reasons.
\end{abstract}

Keywords:-media regime, the effects of the media, students, media literacy

\section{INTRODUCTION}

The media, including television, radio, the Internet, movie, newspaper, magazine etc.plays a prominent role in forming and influencing the cultures, values, and beliefs of the members of society through increasingly providing them with different information, entertainment and advertisements. In other words, in the new era, the society and especially students and adults are exposed to media messages more than ever due to satellites, the Internet and other modern communicational devices. They also face the pervasiveness of the media in the present society.

The experts of different scientific fields are concerned about the negative aspects of the media. Therefore, some media specialists believe that imposing censorship and installing electronic peripherals on the television in order to prevent children from watching unsuitable programs are necessary. However, the experts of communication believe that the solution to prevent the negative effects of the mediais to promote media literacy. It seems that the best ways to survive in the era of communication and information networks are preserving independence, avoiding passivity, developing critical thinking, increasing the ability to select and challenge this pervasive wave. These ways are only accomplished through developing media literacy (Taherian, 2008).

\section{THE STATEMENT OF THE PROBLEM}

In the present era, the media, whether mass media or modern media, plays a prominent role in people's collective life. It also plays a prominent role in cultural changes, socialization, giving identity, informing the members of society etc., thus applying different types of the media from different aspects and among different social groups has gained importance. In other words, different social groups have been connected to the media based on different cultural-social variables. In fact, cyberspace is sort of large society and co-existence,which has connected millions of users and computers around the world. Today, we live in a media world and our life depends on the media to the extent that the media especially the interactive media (Internet) has an important 
place in our life. This sort of media is particularly attractive to teenagers and adults and their life has been closely connected to interactive media. The most effective ways to reduce emerging social harms as a result of cyberspace and the media are approving law, providing special and safety trainings of how to use the Internet and generally developing a media regime for teenagers. The main aim of the present study is to determine the students' media regime in Tehran's Ministry of Education, district 12. In other words, the main aims of this study are to find which factors are important in determining the students' media regime in this district, how much these students spend time using the media, for what reasons they use it and how the level of their media knowledge is.

\section{THE PURPOSE OF THE STUDY}

The primary aim of this study is to determine the students' media regime in Tehran's Ministry of Education, district 12.

The secondary aims:

- Investigating the priorities of using the media among the students

- Identifying their use of different types of the media

- Investigating that how much they use different types of the media

- Studying their level of knowledge about different media

\section{Research Hypotheses}

The primary hypothesis: it seems that students have different styles in using mass media.

The secondary hypotheses:

* Students spend a lot of time using mass media.

- Students' knowledge about the media is very little.

* Students have different goals in using the media.

\section{THE PLACE OF MEDIA LITERACY IN THE EDUCATION} SYSTEM OF THE COUNTRY

The importance of media literacy in today's world is not less than literacy. Literacy is a necessity in people's social life, however, media literacy is of higher importance in this information era where there are different visual, auditory, and written media. In fact, without this sort of media, we cannot have the right choice of media messages and secure ourselves against the messages of media, thus we must prepare the ground for teaching this literacy alongside the main literacy in the education system of the country. Meanwhile, educational-social institutions such as the ministry of education, universities and educational centers play a prominent role in teaching the media literacy. The ministry of education as the first educational institution, which an individual becomes familiar with, has the main role. In this institution, some courses can be added to lower degrees in order to prepare the students for the topic of media literacy, while in higher degrees, this topic must be taught seriously in separate courses. On the other hand, academic institutions must add the concept of media literacy to students' textbooks. Moreover, the courses of communication faculties are useful as well. Despite the importance of teaching the media literacy to children and teenagers, it is still considered as a new concept, which is not noticed in schools and universities (BasirianJahromi, 2013).

\section{SOCIAL NETWORKS AND THEIR EFFECTS ON LIFESTYLE AND} ADULTS' DAILY LIFE

Lifestyle is a part of life and includes the full spectrum of activities that people do in their daily life, thus the spectrum of different activities done by people in every part of life can build their lifestyle in that part. According to Bourdieu Theory, lifestyle includes the categorized and categorizing activities in different parts of life such as dividing the hours of a day, the type of entertainment and sport, how to communicate, house and furniture, etiquette and generally the individuals' preferences. People, who are optimistic about the development of modern technologies in different dimensions of daily life, predict new opportunities for social and democratic cooperation, creativity, self-expression and game, and the development of accessible knowledge, which supports the variety, difference and debate. The potential effects of new forms of information and communicational technology are related to every aspect of the society from house to work, from training to free time, from citizenship to consumerism and from local level to global level.

\section{THE BACKGROUND OF THE STUDY}

Escardibul, Mora, and Villarroya (2012) analyzed the peer effects on youth screen media consumption in Catalonia (Spain) and concentrated specifically on the time when people watch TV programs, play games or surf the Internet. The results indicated that peer consumption has a significant effect on using the Internet and playing games. 
Tafawa, Viswanath, Kawachi, and Williams (2012) studied the relationship between mass media exposure, social stratification, and tobacco consumption in Nigeria. Mass media exposure is a significant predicting factor in recognizing the appropriate attitude towards tobacco consumption. They stated that a significant number of mass media advertisements concentrate on men's smoking. Two questionnaires were adopted from Nigeria's Health and Treatment Center for men and women. The results indicated that mass media (television, radio, magazines etc.) as the advertiser has a direct and significant effect on the inclination to tobacco consumption among men and women.

Ahmad Khalil (as cited in Hagan, 2012) conducted a research under the title of "What is media consumption?" and investigated the relationship between how much Pakistani watchers are affected by public media and social crimes. According to the results, the more horror and action movies are consumed, the more adults between 18 to 25 are tended to commit the crimes.

Soltanifar (2008) in his study under the title of "Analyzing students' internet literacy of third grade high school in Tehran (2006-2007) in comparison to trainers and parents" concluded that there is a significant difference in the ability to use the Internet between students, trainers, and parents. Moreover, there is a significant difference in the priority of using the Internet and personal planning for using it between students, trainers, and parents.

\section{RESEARCH METHODOLOGY}

The present study is applicable in terms of aim and descriptive-survey in terms of data collection. The aim of applicable researches is to develop the applicable knowledge in a particular field. In other words, applicable researches are guided to the scientific application of knowledge. Since the aim of the present study is to determine the students' media regime in Tehran's Ministry of Education, district 12, it can be concluded that this research is applicable. Researches are divided into five groups according to the nature and method, i.e. descriptive, historical, correlational, experimental and scientific researches. In descriptive researches, the researcher searches for the howness of the topic and wants to know how the current situation is. He also attempts to systematically describe the current situation, study its characteristics and investigate the relationship between the variables (Alvani, Azar\&Danaeefard, 2011). Since in this research, different documents, papers, theses, and books have been applied, field method and questionnaire have been selected as the methodology and it is aimed at determining the students' media regime in Tehran's Ministry of Education, district 12 through using the opinions of these students, thus this research is descriptive-survey.

\section{DATA ANALYSIS}

In this research, in order to compare the information gathered through the questionnaire, two types of statistics have been used, including descriptive and referential statistics. In descriptive statistics, absolute frequency distribution table, percentage, mean, and standard deviation have been used in this research and in referential statistics, statistical tests such as Friedman Test and T-Test have been used to analyze the hypotheses. The first hypothesis: it seems that students have different styles in using mass media.

Table 1ne sample t-test

\begin{tabular}{|c|c|c|c|c|}
\hline $\begin{array}{c}\text { Standard error of } \\
\text { the mean }\end{array}$ & $\begin{array}{c}\text { Standard } \\
\text { deviation }\end{array}$ & Mean & Number & \\
\hline 0.05641 & 0.28512 & 3.9731 & 370 & awareness \\
\hline
\end{tabular}

The results of descriptive statistics test indicate that the mean of sample is 3.9731, which is larger than the grand mean (2.5). Therefore, $\mathrm{H}_{0}$ is rejected and the research hypothesis is confirmed. This fact must be confirmed through referential statistics too.

Table 2Different styles of using the media

\begin{tabular}{|c|c|c|c|c|c|c|}
\hline \multicolumn{2}{|c|}{} & \multicolumn{9}{|c|}{ One sample test } \\
\cline { 2 - 7 } & T value & $\begin{array}{c}\text { Degree of } \\
\text { freedom }\end{array}$ & $\begin{array}{c}\text { Sig. (2- } \\
\text { tailed) }\end{array}$ & $\begin{array}{c}\text { The difference } \\
\text { between sample } \\
\text { mean and tested } \\
\text { value }\end{array}$ & \multicolumn{2}{|c|}{$\begin{array}{c}\text { Level of significance } \\
(95 \%)\end{array}$} \\
\cline { 4 - 7 } & & 0.369 & 0.000 & 1.47690 & 1.42690 & 1.2895 \\
\hline $\begin{array}{c}\text { Different styles } \\
\text { of using the } \\
\text { media }\end{array}$ & 21.814 & & & & & \\
\hline
\end{tabular}


Since the level of significance for the above test is smaller than $5 \%$, different styles of using the media by students are higher than the desired level. The significance of mean difference is confirmed by means of sig. value, which is 0.000 . Since this value is smaller than $5 \%$, thus at the significance level of $95 \%, \mathrm{H}_{0}$ is rejected. Moreover, since the upper and lower levels are positive, it is concluded that the mean of this variable is larger than the tested value and this variable is at the upper level of the mean. In fact, it can be stated that students have different styles in using the media and search for some goals.

The second hypothesis: it seems that students spend a lot of time using mass media.

Since the data was distributed normally, Student's t-Test has been conducted to test this hypothesis.

Table 3The period of using the media

\begin{tabular}{|c|c|c|c|c|}
\hline $\begin{array}{c}\text { Standard error of } \\
\text { the mean }\end{array}$ & $\begin{array}{c}\text { Standard } \\
\text { deviation }\end{array}$ & Mean & Number & \\
\hline 0.12239 & 0.53348 & 3.0347 & 370 & $\begin{array}{c}\text { The period of } \\
\text { using the media }\end{array}$ \\
\hline
\end{tabular}

The results of descriptive statistics test indicate that the mean of sample is 3.0.347, which is larger than the grand mean (2.5). This value is greater than the desired level and this fact must be confirmed through referential statistics too.

Table 4The period of using the media

\begin{tabular}{|c|c|c|c|c|c|c|}
\hline \multicolumn{2}{|c|}{ One sample test } \\
\cline { 2 - 7 } & T value & $\begin{array}{c}\text { Degree of } \\
\text { freedom }\end{array}$ & $\begin{array}{c}\text { Sig. } \\
(2- \\
\text { tailed) }\end{array}$ & $\begin{array}{c}\text { The difference } \\
\text { between } \\
\text { sample mean } \\
\text { and tested } \\
\text { value }\end{array}$ & $\begin{array}{c}\text { Level of } \\
\text { significance }(95 \%)\end{array}$ \\
\cline { 2 - 7 } & 17.201 & 0.369 & 0.000 & -0.5321 & 2.3624 & 1.8481 \\
$\begin{array}{c}\text { The period of } \\
\text { using the } \\
\text { media }\end{array}$ & & & & & & \\
\hline
\end{tabular}

Since the level of significance for the above test is smaller than $5 \%$, the period of using the media is higher than the desired level. Moreover, since the upper and lower levels are positive, it is concluded that the mean of this variable is larger than the tested value and this variable is at the upper level of the mean. Therefore, the period of using the media by students is greater than the grand mean (2.5) and students spend a large period of time using the media.The third hypothesis: it seems that students' knowledge about the media is very little.

Since the data was distributed normally, Student's t-Test has been conducted to test this hypothesis.

Table 5Students' knowledge about the media

\begin{tabular}{|c|c|c|c|c|}
\hline $\begin{array}{c}\text { Standard error of } \\
\text { the mean }\end{array}$ & $\begin{array}{c}\text { Standard } \\
\text { deviation }\end{array}$ & Mean & Number & \\
\hline 0.12239 & 0.53348 & 2.1613 & 370 & $\begin{array}{c}\text { Students' } \\
\text { knowledge about } \\
\text { the media }\end{array}$ \\
\hline
\end{tabular}

The results of descriptive statistics test indicate that the mean of sample is 2.1613, which is smaller than the grand mean (2.5). This value is lower than the desired level and this fact must be confirmed through referential statistics too.

Table 6Students' knowledge about the media

\begin{tabular}{|c|c|c|c|c|c|}
\hline \multicolumn{6}{|c|}{ One sample test } \\
\hline & \multicolumn{7}{|c|}{ Test value $=2.5$} \\
\cline { 2 - 6 } & T value & $\begin{array}{c}\text { Degree of } \\
\text { freedom }\end{array}$ & $\begin{array}{c}\text { Sig. (2- } \\
\text { tailed) }\end{array}$ & $\begin{array}{c}\text { The difference } \\
\text { between sample }\end{array}$ & $\begin{array}{c}\text { Level of } \\
\text { significance (95\%) }\end{array}$ \\
\hline
\end{tabular}




\begin{tabular}{|c|c|c|c|c|c|c|}
\hline & & & & $\begin{array}{c}\text { mean and tested } \\
\text { value }\end{array}$ & lower & Upper \\
\hline $\begin{array}{c}\text { Students' } \\
\text { knowledge } \\
\text { about the } \\
\text { media }\end{array}$ & 14.804 & 368 & 0.011 & -0.5321 & -1.8221 & -1.1257 \\
\hline
\end{tabular}

Since the level of significance for the above test is larger than $5 \%$, students' knowledge about the media is lower than the desired level. Moreover, since the upper and lower levels are negative, it is concluded that the mean of this variable is smaller than the tested value and this variable is at the lower level of the mean. Therefore, students' knowledge about the media is lower than the grand mean (2.5) and students are not media literate.The fourth hypothesis: it seems that students have different goals in using the media.

Friedman Test is used for two-way analysis of variance (non-parametric data) through ranking and for comparing the mean of different groupsranking. The number of individuals in the samples must be equal. This feature is one of the disadvantages of this test.

Table 7Comparing the mean of different groups ranking

\begin{tabular}{|l|l|}
\hline \multicolumn{2}{|l|}{ Test Statistics $^{\mathbf{a}}$} \\
\hline $\mathrm{N}$ & 370 \\
\hline Chi-Square & 74.435 \\
\hline df & 361 \\
\hline Asymp. Sig. & 0.000 \\
\hline a. Friedman Test & \\
\hline
\end{tabular}

Table 7 indicates the value of Chi-Square, degree of freedom and level of significance. Since the level of significance is lower than $5 \%$, the claim that the ranks of variables are equal is not confirmed.

\section{CONCLUSION}

The results of first hypothesis indicated that students have different styles in using mass media and search for some goals. In other words, students use the media for different reasons. According to the theory of uses and gratifications, individuals actively search for content, which gives the highest gratification. The degree of this gratification depends on the individual's needs and favorites. The more people feel that the real content of their needs are accomplished, the more it is probable that they choose this content. The results of second hypothesis indicated that students spend a large period of time using the media. The results of this hypothesis will help the managers of the media with good planning and enable the parents and trainers to measure the educative effects of the media on their children and students. The results of third hypothesis indicated that students are not media literate.Bakhtiarzadeh (2002) conducted a research under the title of "An investigation into information literacy of students of Alzahra University". The research methodology was descriptiveanalytical and the data-gathering tool was questionnaire. The results indicated that the information literacy of the research population was at a low level. This result is in line with the result of the present study. Tayyebnia (2005) conducted a research under the title of "Investigating the postgraduate students' information literacy of Faculty of Economics, AllamehTabataba'i University". The results of this study indicated that the postgraduate students' information literacy of Faculty of Economics, AllamehTabataba'i University is higher than the average level, which is not in line with the results of the present study.Miri and CheshmeSohrabi (2011) conducted a research under the title of "Investigating the senior students' information literacy of University of Science and Technology, Arak Branch in the digital environment (2008 - 2009)". They did the research through survey-analytical method and investigated the information literacy of 213 senior students according to the standards of America Library Association. The results indicated that the information literacy of studied population is lower than the average level, which is in line with the results of the present study. The results of fourth hypothesis indicated that students use the media with different goals, in other words, they use it according to their needs. The students selected "entertainment" as the most important reason of using the media. 


\section{RECOMMENDATIONS}

$\checkmark$ The necessity of adding the topic of media literacy to school syllabus

$\checkmark$ The necessity of arranging the educational content of communicational technologies

$\checkmark$ Familiarizing the parents with media literacy

$\checkmark$ Generalizing computer literacy of trainers and developing the utilization of modern educational technologies

$\checkmark$ Developing the influence of internet and intranet through filling the digital gaps

\section{REFERENCES}

[1] Alvani, M., Azar, A., \&Danaeefard, H. (2011).The methodology of qualitative research in management: A comprehensive approach. Tehran, Iran: Eshraghi Publishing.

[2] Bakhtiarzadeh, A. (2002). An investigation into information literacy of students of Alzahra University (Unpublished master's thesis).School of Management and Medical Informatics, Tehran.

[3] BasirianJahromi, H. (2013). Social media: Dimensions and capacities. Tehran, Iran: Ministry of Culture and Islamic Guidance, the Center of Media Researches and Studies.

[4] Escardibul, J-O., Mora, T., \&Villarroya, A. (2012). Peer effects on youth screen media consumption in Catalonia (Spain). Journal of Cultural Economics, 37(2), 185-201.

[5] Hagan, F. E. (2012). Introduction to criminology: Theories, methods, and criminal behavior (8thed.). Thousand Oaks, USA: SAGE Publications.

[6] Miri, E., \&CheshmeSohrabi, M. (2011). Investigating the senior students' information literacy of University of Science and Technology, Arak Branch in the digital environment (2008-2009). Quarterly Journal of Epistemology, 4(13), 65-76.

[7] Soltanifar, M. (2008).Analyzing students' internet literacy of third grade high school in Tehran (20062007) in comparison to trainers and parents.Educational Innovations, 7(27), 37-60.

[8] Tafawa, A. O., Viswanath, K., Kawachi, I., \& Williams, D. R. (2012).Mass media exposure, social stratification, and tobacco consumption among Nigerian adults.Cancer Causes Control, 1, 45-55.

[9] Taherian, M. (2008). Media literacy: Media training of children and teenagers. Research Bulletins, 22, 171-196.

[10] Tayyebnia, V. (2005).Investigating the postgraduate students' information literacy of Faculty of Economics, AllamehTabataba'i University (Unpublished master's thesis).Islamic Azad University, Science and Research Branch, Tehran. 